\title{
KRITIKH \}ADI<TH DALAM PERSPEKTIF STUDI KONTEMPORER
}

$\operatorname{Idr}^{*}$

\begin{abstract}
Critical studies of $h$ \}adi $>$ th donot alwaysaimat arguingagainst thelegitimagy of $h$ \}adi $>$ th as oneof thesaurces of IsamicLaw Nordbit dault-likemany orientalist would do theauthentiaty of the $h$ \}adi $>$ th as a sarce of Istamic teaching Critical studies of $h$ \}adi $>$ th areabat investigating theacuray and validity of thenamation dhain Considaing that many h\}adi > thstakea longperiod of timebforethey arebingnamated, inacouragy might havetaken placein that process. Thereforea citiqueisneeded. In the context of contemporarylife a citiqueis even mmeneeded espeially that whichlokksat $h$ \}adi $>$ thin tems of its relation withmodem siene, tehndogy, gender issues, human nights, freetomof expression, andsoon This paper disasses thenotion of thecitical studies of $h$ hadi>thin contemporary lifeby fousing on far issues (1) the cognitive foundation of the studies, (2) the djeets of the citique, (3) the neessity of the citique, and (4) thenomative standards of thecritique
\end{abstract}

Keywords: citique, h\}adi>th, sanad, matn

\section{Pendahuluan}

Kata 'kritik' mengandung konotasi negatif ketika dimaksud dalam konteks sebagai koreksi atas kesalahan suatu hal tertentu. Jika dikaitkan dengan $\mathrm{h}$ \}adi>th $\mathrm{Nabi}$, dalam konteks pemahaman demikian, kesan yang diperoleh dari kata kritik $\mathrm{h}$ \}adi>th adalah terdapat kesalahan dalam $\mathrm{h}$ \}adi>th Nabi dan karenanya diperlukan kritik dan/ atau koreksi. Kesan ini juga terdapat dalam pembicaraan keseharian orang Indonesia yang menempatkan kata kritik pada makna tidak lekas percaya, tajam dalam analisa, dan pertimbangan baik buruknya suatu karya. ${ }^{1}$

Pengertian demikian dapat diterima bila dimaksudkan pada realita bahwa dari sekian banyak $\mathrm{h}$ \}adi>th dalam berbagai literatur $\mathrm{h}$ \}adi>th atau non-h\}adi>th, ada beberapa yang dipertanyakan validitas dan akurasinya. Persoalannya terletak pada penilaian terhadap transmisi dan materi h\}adi>thh\}adi>th yang berakibat pada distingsi kualitas dan memotivasi kritik serta klarifikasi secara eksternal maupun internal.

Secara bahasa, kata kritik (citicize: Ing.) dapat berdenotasi positif berupa pembuatan penilaian tentang kebaikan atau keburukan sesuatu (to make judgements abat the good and bad paints of). K ritik positif melibatkan pertimbangan rasional-objektif ketika menilai sesuatu, berbeda dengan kritik negatif yang lebih bersifat mengadili dengan penolakan (to judge with disaproval). ${ }^{2}$ Penolakan a prioi yang cenderung membawa pada penilaian buta untuk kategori kedua, karena adanya asumsi dasar berupa negasi dan ketidaksukaan terhadap objek yang dinilai.

Seorang kritikus (aitid, pada satu sisi, dapat bertindak sebagai penilai positif tentang baik atau buruknya kualitas sesuatu (a peson who gives judgements abat the good and bad qualities of somthing secara independen, objektif, dan fair dan pada sisi yang lain, ia bertindak sebagai orang yang tidak suka atau

\footnotetext{
* Sekolah Tinggi A gama Islam Negeri (STAIN) Pamekasan, Madura, Jawa Timur.

${ }^{1}$ D epartemen Pendidikan dan Kebudayaan, KamsUmmBahasaIndonesia(Jakarta: Balai Pustaka, 1988 M.), 466.

${ }^{2}$ Longman, Didionaryof ContemporaryEngish(O xford : O xford University Press, 1988 M.), 243.

${ }^{3}$ Ibid.
} 
mengungkapkan penolakan kuat terhadap sesuatu atau seseorang (a pesson who disikes and expresses strong disaproval of samthing ar samene). ${ }^{3}$

Dalam kajian $\mathrm{h}$ \}adi>th, kritik dimaksudkan pada bentuk yang positif ketika kritikus menempatkan diri pada posisi objektif untuk menilai $\mathrm{h}$ \}adi>th dan periwayatnya; apakah kandungan h \}adi>th itu valid (absah) dan secara historis dapat dipertanggungjawabkan atau tidak, bukan kritik dalam pengertian negatif di mana sikap a proi didahulukan untuk menolak suatu h\}adi>th. Sikap objektif menjadi barometer utama kritik untuk menghindari bias (bias contrast effet) dan subjektifitas yang dapat merusak nilai kebenaran studi h \}adi>th. Umat muslim, demikian komentar John Burton, menyadari resiko dan bahaya dari sikap subjektif sehingga semua informasi $h\}$ adi >th penting disampaikan dan disebarkan untuk mengatasi subjektifitas penilaian yang dilakukan (to owe-sugjetirity in the judgenents reached). ${ }^{4}$

Kritik $\mathrm{h}$ \}adi>th, yang dalam bahasa Arab dikenal dengan naqd al-hadis berasal dari akar kata naqd dan al-h\}ad>th Kata naqd sendiri berarti penelitian, analisis, pengecekan, dan pembedaan. ${ }^{5}$ Sehingga, dalam bingkai makna ini, kritik $\mathrm{h}$ \}adi>th mencakup penelitian kualitas $\mathrm{h}$ \}adi>th, analisis terhadap sanad dan matan-nya, pengecekan $\mathrm{h}$ \}adi>th ke dalam sumber-sumber, serta pembedaan $\mathrm{h}$ \}adi>th otentik dan yang tidak. Meskipun penggunaan kata al-naqd tidak ditemukan dalam nash al$\mathrm{Q}$ ur'a $>\mathrm{n}$ ataupun $\mathrm{h}$ \}adi $>$ th, tidak berarti bahwa konsep kritik tidak dikenal dalam al-Q ur'a $>\mathrm{n}$. Sebab, pada kenyataannya, al-Q ur'a>n menggunakan kata yami $>z^{6}$ (bentuk mo\}a $>r^{\prime}$ dari kata ma $>z a$ ) untuk maksud ini yang berarti memisahkan dan membedakan sesuatu dari sesuatu yang lain. Barangkali berangkat dari konsep inilah Muslim bin al-Hajjaj pada abad ketiga Hijriyah (w. 261 H.) memberi judul bukunya yang membahas kritik $\mathrm{h}$ \}adi $>$ th dengan kitab al-Tamji $>\mathrm{z}$

Dalam tradisi kritik h\}adi>th klasik, kata al-naqd jarang diapliklasikan untuk pengertian kritik. Istilah yang populer untuk kritik h\}adi>th masa itu dan masa-masa berikutnya adalah al-jarh\} wa alta'di $>$ lyang berarti kritik negatif dan kritik positif sebagai instrumen untuk mengukur kualitas $\mathrm{h}$ \}adi>th atau periwayatnya. Bila dicermati definisi kata al-naqd menurut Abu Hatim al-Razi (w. 327 H.) sebagai upaya menyeleksi (membedakan) antara $\mathrm{h}$ \}adi>th s\}ah\}i $>\mathrm{h}\}$ dan d\}a $\mathrm{a}>\mathrm{f}$ serta menetapkan status perawi-perawinya dari segi keterpercayaan atau cacat, ${ }^{7}$ maka istilah al-jarh\} wa al-ta'di $>1$ relevan dengan naqdal-h\}adi >th Kesesuaian dua term ini lebih jelas terlihat pada definisi kritik yang dikemukakan alJawabi dalam bukunya Juh\} $>$ d al-Muh\}ddithi>n

"Penetapan status cacat atau 'adil pada periwayat $\mathrm{h}$ \}adi>th dengan mempergunakan idiom khusus berdasar bukti-bukti yang mudah diketahui oleh para ahlinya, dan mencermati matan-matan $\mathrm{h}$ \}adi>th sepanjang shahih sanad nya untuk tujuan mengakui validitas atau menilai lemah, dan upaya menyingkap kemusykilan pada matan dengan mengaplikasikan tolak ukur yang detail". ${ }^{8}$

D engan demikian, kritik $\mathrm{h}$ \}adi>th tidak dimaksud sebagai instrumen pengujian validitas h\}adi>th-h\}adi>th dalam kapasitasnya sebagai sumber ajaran Islam yang dibawa Nabi Muhammad karena status keterjagaannya dari kesalahan (al-ma's\} $\mathbf{l}>\mathrm{m}$ ) tetapi pada tataran akurasi dan validitas

${ }^{4}$ John Burton, AnIntrodudion totheHadith(E dinburgh : Edinburgh University Press, tth.), xii.

${ }^{5}$ Hans Wehr, A Didionaryof ModernWittenArabic(London: G eorge Allen \& Unwin Ltd., 1970 M.), 990.

${ }^{6}$ al-Q ur'a $>$ n, 3 (Ali 'Imran): 179.

${ }^{7}$ Muhammad Mustafa Azami, Manhaj al-Naqd indaal-Muhaddiŝn(Riyad\}: al-Ummariyah, 1982), 5.

8al-Jawabi, Juhu>dal-Muhaddithi>n(Tunis: Muassasah 'Abd al-K arim, 1986), 94. 
transmisi informasi $\mathrm{h}$ \}adi>th yang pada akhirnya berakibat pada nilai otentisitasnya, mengingat masa kodifikasinya cukup panjang hingga memerlukan mata rantai periwayat penyampai informasi dalam bentuk sanad berbeda dengan al-Q ur'a $>n$ yang dibukukan tidak lama setelah Nabi wafat. Rentang waktu lama itulah penyebab diperlukannya kritik untuk mengetahui akurasi dan validitasnya. Meskipun, belakangan kritik materi h\}adi>th (matan) juga menjadi perhatian pokok terutama dengan kemunculan isu-isu kontemporer seperti ilmu pengetahuan dan teknologi, gender, hak azazi manusia, kebabasan berpikir, dan sebagainya.

Permasalahan yang muncul dalam tulisan ini berkenaan dengan kritik $\mathrm{h}$ \}adi>th dalam perspektif kontemporer dengan fokus pada : [1] landasan kognitif kritik h\}adi>th, [2] objek kritik h\}adi>th, [3] urgensitas kritik h\}adi>th, dan [4] standarisasi kritik h\}adi>th.

\section{Landasan Kognitif Kritik $\mathbf{H}$ \}adi>th}

Kritik h\}adi>th, layaknya kritik ilmiah umumnya, memerlukan dasar-dasar kognitif sebagai landasan pemikiran, sebab seperti dinyatakan Muhammad 'Abid al-Jabiri, sebuah kritik yang tidak mengenal dasar-dasar kognitif sebagai landasan subjeknya hanya akan menyisakan kritik ideologis terhadap ideologi dan tidak menghasilkan apapun kecuali ideologi pula. Untuk itu, diperlukan kritik yang memenuhi persyaratan keilmiahan, yaitu kritik yang diarahkan pada cara produksi (mode of production) sebuah teori yang berupa tindakan mental. Kritik semacam ini yang dapat membuka jalan bagi pembacaan ilmiah yang objektif. ${ }^{9}$ Kritik h\}adi>th seharusnya bersifat terbuka, dapat diuji ulang kebenarannya (testability), dan tidak terkungkung dalam lingkaran ideologi-subjektif penyebab pelanggaran prinsip-prinsip kritik dan penilaian seperti validitas, keterhandalan, transparansi, adil, dan otentisitas.

Para ahli h\}adi>th telah mengembangkan prinsip-prinsip dasar kritik h \}adi>th (dra>yah alh\}ad $>$ th) yang dapat diklasifikasi ke dalam dua kategori : (i) yang berhubungan dengan sistem isnâd, dan (ii) yang berhubungan dengan matan h\}adi>th. O bjek yang paling banyak dikaji dalam literatur h\}adi>th terkait dengan sistem isnâd adalah masalah biografi dan penilaian terhadap para periwayat h\}adi>th (asma >' al-ijja>l) yang menyangkut : (a) kronologi waktu, (b) biografi, (c) penilaian terhadap para periwayat h \}adi>th, (d) khirarkhi mereka dalam status sebagai periwayat, (e) aspek-aspek kehidupan mereka yang memungkinkan membantu dalam menentukan identitas, kebenaran, dan keabsahan mereka, (f) bukti-bukti h\}adi>th riwayat mereka disertai komentar kritikus $\mathrm{h}$ \}adi>th, ${ }^{10}$ dan (g) metode penyampaian dan penerimaan $\mathrm{h}\}$ adi $>$ th.

Penilaian terhadap sistem isna $>d$, asal-usul, dan penerapannya dalam $h$ \}adi $>$ th, ${ }^{11}$ perkembangannya, asal usul dan perkembangan literatur biografi, kualifikasi para periwayat, dan halhal lain terkait menjadi objek kajian $h$ \}adi>th dari segi sanad dalam studi $h$ \}adi>th. Para ulama h \}adi>th

${ }^{9}$ Muhammad 'Abid al-Jabiri, Kritik PemikiranIdam terjemahan (Yogyakarta : Fajar Pustaka Baru, 2003 M.), hh. 13-14 ${ }^{10 L}$ Lihat: Abu Hatim al-Razi, Kita>bbal-Jarh\} waal-Tádi>l (Heiderabad: Majlis D airah al-Ma'arif, 1952 M.), al-D hahabi>, Tadkkirah al-Huffa $>$ z , juz I (Heiderabad: The D airat el-Maarif el-O thmaniya, 1955), A hmad bin Hajar al-'Asqalani, Tahdhi $>$ bal-Tahdhi $>$ b (Beirut: D a>r al-Kutub al-'Ilmiyah, 1987 M.), pengarang yang sama, Lisa>nal-Miza>n, cet. I (Beirut: D a $>$ r al-Kutub al'Ilmiyyah, 1416 H./ 1996 M.), dan al-D hahabi, Miza>nal-T'tida>lfi> Naqdal-Rija>l, juz I (Beirut: Da>r al-Kutub al-'Tlmi>yah, 1995 M.).

${ }^{11}$ Sistem isma>dyang diyakini telah ada pada masa Nabi bahkan masa pra-Islam, seperti terlihat pada kitab Yahudi Mis\}na $>$ dan dalam pengutipan syair-syair Jahiliyah, telah digunakan secara intens terutama sejak terjadi pemalsuan hadis masa Ali ibn Abi 
cenderung mengkaji sanad lebih sebagai bagian eksternal dan sekaligus penunjang bukti kebenaran matan $h$ \}adi>th. Sebagai silsilah orang-orang yang menghubungkan kepada matan $h$ \}adi $>\operatorname{th}^{12}$ atau jalan menuju matan, yaitu mata rantai periwayat yang menyampaikan matan (materi) h\}adi>th dari sumbernya yang pertama, ${ }^{13}$ sanad mempunyai peran penting dalam pembuktian keabsahan matan h \}adi>th karena dengan sanad, h\}adi>th dapat dibuktikan kebenarannya secara historis.

Prinsip-prinsip kritik sanad secara garis besar dapat diringkas sebagai berikut.

[1] Setiap h \}adi>th harus dapat diurut ke belakang sampai penerima dan penyampai yang pertama dengan mata rantai yang bersambung di antara para periwayat yang memiliki identitas yang jelas, sifat yang tidak dipertanyakan, serta kualitas kecerdasan (ingatan) dan ketinggian ke-adl-an yang mapan.

[2] Setiap h\}adi>th yang merekam suatu peristiwa yang kadang-kadang dihadiri orang banyak, harus diriwayatkan sebagaimana aslinya oleh beberapa periwayat. ${ }^{14}$

[3] Setiap h\}adi>th harus terhindar dari sifat-sifat yang merusak nilai kesahihannya baik karena di dalamnya terdapat cacat tersembunyi ('illat) atau kejanggalan ( $($ ha $>$ dh) yang diketahui setelah dilakukan penelitian lebih dalam.

Obyek kajian matan h\}adi>th pada dasarnya berkenaan dengan dua aspek : (i) bentuk redaksi dan (ii) kandungan matan. Kritik h \}adi>th dari segi matan berkenaan dengan redaksi dan/ atau kandungan makna yang menunjukkan $\mathrm{h}$ \}adi>th itu tidak berisi kedustaan terhadap Rasulullah baik perkataan yang pernah diucapkan atau perbuatan yang pernah dilakukan. ${ }^{15}$ Berbeda dengan kritik sanad dan berhubung tidak ada kesepakatan tentang prinsip-prinsip dan standar penilaian yang digunakan, aplikasi kritik matan lebih sulit dari pada kritik sanad. Jika barometer kritik sanad jelas dalam lima prinsip atau kriteria ${ }^{16}$ sehingga untuk mengukurnyapun lebih mudah, tidak demikian dengan prinsip-prinsip kritik matan yang jumlahnya relatif lebih banyak dan tidak ada kesepakatan ulama h\}adi>th tentang batasan-batasannya.

Karena itu, untuk mengetahui kesahihan $\mathrm{h}$ \}adi>th dari segi matan, berbeda dengan kritik dari segi sanad, seorang kritikus menurut Ibn al-Q ayyim al-Jawziyyah (w. 751 H./ 1350 M.), harus memenuhi kualifikasi tertentu, yaitu: (a) mengetahui sejarah hidup Nabi, (b) mengetahui petunjuk-petunjuk Nabi, (c) mengetahui segala yang diperintah dan dilarang Nabi, (d) mengetahui segala yang disenangi dan

Thalib (w. 40 H./ 661 M.). Para ulama berusaha agar tiap h\}adi>th diriwayatkan tidak hanya matannya saja tapi sekaligus dengan sanadnya. Pada masa ta $>$ bi $i>n$, penerapan sistem isnadsudah memasyarakat, tidak hanya dikenal di kalangan ulama saja tapi juga di kalangan umum. Lihat : Muhammad Musthafa Azami, Studies in Hadith Metoddogyand Literature(Indianapolis: IslamicTeaching Center, 1977), 530, Muhammad 'Ajjaj al-K hathib, al-Sunnahqad al-Tadwín(Beirut: Da >r al-Fikr, 1971 M.), 220 dan pengarang yang sama, Us\}u>l al-H $\{$ adi $>$ th Ulu>muhwaMus\}t\}alahuh(Beirut: $\mathrm{D}$ a $>\mathrm{r}$ al-Fikr, 1989), 224.

${ }^{12}$ Mahmud al-T \{ahha>n, Taysi>rMust\}alah\} al-H \{adi>th(Beirut: D a>r al-Q ur'a>n al-Karim, 1979 M.), 16.

${ }^{13}$ al-K hat $\left.\} \mathrm{i}>\mathrm{b}, \mathrm{Us}\right\} \mathrm{u}>\mathrm{lalH}\{\mathrm{adi}>$ th 32 .

${ }^{14}$ Muhammad Zubayr Siddiqi, "The Sciences and Critique of Hadith", dalam P.K. Koya (ed.), HadithandSumnah: Idaalsand Reelities(Kuala Lumpur : Islamic Book Trust, 1996 M.), 95.

${ }^{15}$ 'Umar bin Hasan 'Uthman Fallatah, al-Wad\}' fi> al-H \{adi>th juz I (Beirut: Muassasah Manahil al-'Irfa>n, 1981 M/ 1401 H.), 300.

${ }^{16} \mathrm{~K}$ riteria h\}adi>th s\}ah\}i>h\} adalah : (a) sanadnya bersambung, (b) periwayat 'adil, (c) periwayat d\}abit\}, (d) terlepas dari sha $>$ dh dan (e) terhindar dari 'illat. Lihat: Ibn al-S \{alah, 'Ulu>mal-H \{adi>th(Madinah: Maktabah al-Islamiyah, 1972), 10, Ibn Hajar al-'A sqalani, Sharh\} Nuhbatal-Fikrfi $>$ Mus\}t\}alah\} Ahlal-Atha $>r$ (Beirut: D a $>$ r al-Atha $>$ r, 1984), 51, al-Q asimi, Qava $>$ 'id al-Tah\}d >thminFunu>nMus\}t\}atah\} al-H \{ad>th(Beirut: $\mathrm{D}$ a $>$ r al-Kutub al-'Ilmiyah, 1979), 79, al-Suyuti, Tadri $>$ bal-Ra $>$ w> $>$

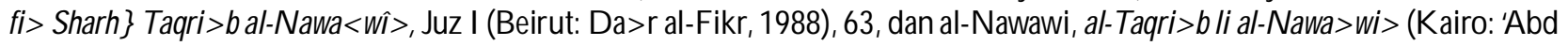
al-Rahman Muhammad, tth.), 2. Kriteria (a), (b), dan (c) berkenaan dengan sanad dan (d) serta (e) terkait dengan sanad dan matan. 
dibenci Nabi, dan (e) mengetahui segala yang disyariatkan Nabi seolah-olah telah lama bercampurbaur seperti salah seorang sahabatnya. ${ }^{17}$

Menurut M. Syuhudi Ismail, kualifikasi yang harus dimiliki oleh seorang kritikus $h$ \}adi>th dari segi matan adalah : (a) memiliki keahlian di bidang $h$ \}adi>th, (b) memiliki pengetahuan yang luas dan dalam tentang ajaran Islam, (c) telah melakukan pengkajian secara mendalam, (d) memiliki akal yang cerdas, dan (e) tradisi keilmuannya tinggi. ${ }^{18} \mathrm{D}$ engan kelima kualifikasi ini, seorang kritikus dapat menilai bahwa suatu h\}adi>th sahih atau tidak dari segi matan, tanpa melihat sanadnya sekalipun.

D engan kualifikasi di atas dan disertai pengetahuan tentang prinsip-prinsip kritik matan $\mathrm{h}$ \}adi>th, seorang kritikus dapat meneliti kualitas $\mathrm{h}$ \}adi>th dari segi matan semata secara akurat. Menurut Shalah al-D in al-Adabi, prinsip-prinsip itu secara garis besar sebagai berikut : [1] Tidak bertentangan dengan al-Qur'a $>n$, [2] Tidak bertentangan dengan $h\}$ adi $>$ th s\}ah\}i $>$ h\} [3] Tidak bertentangan dengan alsrah al-nabawiyah [4] Tidak bertentangan dengan akal, [5] Tidak bertentangan dengan indera, [6] Tidak bertentangan dengan sejarah, [7] $\mathrm{H}$ \}adi>th yang tidak menyerupai perkataan $\mathrm{Nabi}$, [8] $\mathrm{H}$ \}adi>th yang mengandung keserampangan, [9] $\mathrm{H}$ \}adi>th yang mengandung makna yang rendah, dan [10] $\mathrm{H}$ \}adi>th yang lebih menyerupai pernyataan ulama khalaf. ${ }^{19}$

Menurut Muhammad Zubayr Siddiqi, otentisitas h\}adi>th dapat diketahui melalui penerapan prinsip-prinsip kritik matan berikut :

1] Suatu $h$ \}adi>th tidak boleh bertentangan dengan $h$ \}adi>th-h $\}$ adi $>$ th lain dalam masalah yang sama, yang telah diterima sebagai $\mathrm{h}$ \}adi>th yang sahih oleh periwayat lain yang berkompeten. Tidak boleh pula bertentangan dengan teks al- $\mathrm{Q}$ ur' $\mathrm{a}>\mathrm{n}$ atau prinsip-prinsip dasar Islam yang telah diterima.

2] Suatu h\}adi>th tidak boleh bertentengan dengan akal, hukum alam, dan pengalaman umum.

3] $\mathrm{H}$ \}adi>th-h \}adi>th yang menerangkan tentang balasan (pahala) yang tinggi yang tidak proporsional bagi perbuatan baik dan tidak signifikan atau hukuman berat yang tidak proporsional untuk kesalahan biasa harus ditolak.

4] $\mathrm{H}$ \}adi>th-h $\}$ adi $>$ th yang memuat nilai-nilai yang luar biasa surat-surat dalam al-Q ur'a $>\mathrm{n}$ tidak harus diterima semuanya secara umum.

5] $\mathrm{H}$ \}adi>th-h \}adi>th yang mengandung kelebihan dan pujian kepada seseorang, suku, atau tempattempat tertentu harus ditolak secara umum.

6] $\mathrm{H}$ \}adi>th-h \}adi>th yang memuat ramalan-ramalan masa depan dengan menyebutkan waktu haruslah ditolak.

7] $\mathrm{H}$ \}adi>th-h \}adi>th yang memuat pernyataan-pernyataan Nabi yang bisa menghambat posisi kenabiannya serta ungkapan yang mungkin tidak sesuai dengan dia seharusnya ditolak. ${ }^{20}$

Di samping berdasar prinsip-prinsip di atas dan untuk memenuhi obyektifitas yang tinggi, memenuhi standar penelitian ilmiah, untuk menghindari bias, dan agar tercapai sikap keterbukaan wacana dan keterbebasan dari dogmatisme, maka kritik h \}adi>th seharusnya memenuhi standar-standar

${ }^{17} \mathrm{Ibn}$ al-Q ayyim al-Jawziyah, al-Mana>ral-Muni>f fi>al-S\{ah\}i>h\} waal-D \{ai $>f(B e i r u t: D$ a $>$ al-Kutub al-'Tlmiyah, 1988 M.), 37.

${ }^{18} \mathrm{M}$. Syuhudi Ismail, Meødog Penditian HadisNabi (Jakarta: Bulan Bintang, 1992 M.), 130.

${ }^{19}$ S $\{$ alah al-Di $>$ n bin Ahmad al-Ad\}abi, Manhaj Naqdal-Matn'ind 'Ulama>' al-H \{adi>thal-Nabavi> (Beirut: Da>r al-Afla>q alJadi>dah, 1983), 197-288.

${ }^{20}$ Muhammad Zubayr Siddiqi, TheSaienes 96.

${ }^{21}$ al-K hat\}i $>$ b, Us\}u>lal-H \{adi>th, 262. 
penelitian ilmiah berikut.

Petama, keteguhan pendirian (nigr) yang menghendaki kritik dilaksanakan dengan penuh kehatihatian, bersikap seksama dan cermat, serta mempunyai derajad akurasi yang tinggi terhadap setiap bentuk kajian dan riset $\mathrm{h}$ \}adi>th yang dilakukan. Suatu kritik $\mathrm{h}$ \}adi>th yang didasari dengan pengetahuan memadai tentang epistemologi studi $\mathrm{h}$ \}adi>th akan menambah keteguhan hati terhadap studi dan tanpa sikap dasar semacam ini seringkali kritik tidak menghasilkan kesimpulan yang tepat. Sikap ini (nigr) pernah ditunjukkan oleh Syu'bah ibn al-Hajjaj (82-160 H.) ketika ditanya tentang h \}adi>th yang diriwayatkan Hakim ibn Jubayr. Syu'bah yang dikenal sangat keras terhadap para pendusta h\}adi>th berkata, "Aku takut pada neraka" ${ }^{21}$ Karena ketegasan dan keteguhan inilah, alSyafi'i berkomentar, Seandainya tidak ada Syurbah niscaya h\}adi $>$ th tidak dikenal di Iraqu ${ }^{22}$

Kedua, dapat diuji kebenarannya (testability), yaitu hasil kritik yang berupa kesimpulan yang diperoleh dari kajian empirik $\mathrm{h}$ \}adi>th dengan pendekatan induktif, harus dapat diuji kebenarannya baik oleh orang-orang sezaman dengan periwayat maupun orang-orang sesudahnya. Pengujian dapat terjadi satu kali atau berulang kali (redicability). Ini dimaksudkan untuk mengapresiasi ilmu (dalam hal ini 'ilmh\}adi>thal-dra>yahsebagai landasan kognitif dan epistemologis), yang dimungkinkan mengalami perubahan dan menerima kritik (qa>bil li al-taghyi $>$ r wa al-niqa $>$ sh) meskipun secara substansial materi h\}adi>th tidak diperbolehkan mengalami perubahan. Suatu ketika al-Sya'bi pernah berkata, Demi Allah, sckiranya aku mdakukan kebenaran sembilan puluh sembilan kali dan kesalahan skali saja, tentulah merka merilaiku backsarkan yang sdkali itu ${ }^{23}$

Ketiga, keterpercayaan (confidentiality) menjadi prasyarat mutlak bagi kritik h\}adi>th karena data kajian bersangkut paut dengan fakta-fakta masa lampau. Sikap mental objektif dalam membuat kesimpulan hasil kritik benar-benar didasarkan pada fakta yang ditemukan dalam menyusun analisis data. Kesimpulan diambil berdasar fakta yang diperoleh dari data dan tidak berdasarkan subjektifitas individu yang mengandung nilai-nilai emosional, terlebih yang bersifat penolakan (contrast effect) sebagai terlihat dalam pengertian kritik negatif di atas. Dalam studi h\}adi>th, keterpercayaan sangat terkait erat dengan para periwayat $\mathrm{h}$ \}adi>th; tentang tsiqahatau tidaknya mereka. Alfred G uillame menyatakan bahwa kajian tentang karakter periwayat sangat diperlukan terutama untuk mengetahui apakah secara moral atau agama dapat dipertanggungjawabkan, mempunyai reputasi tentang kejujuran, dan mampu meriwayatkan $\mathrm{h}$ \}adi>th yang didengar secara benar. ${ }^{24}$

Keempat, obyektifitas (djeetivity) menghendaki agar suatu $\mathrm{h}$ \}adi>th disampaikan apa adanya (das sin) tanpa intervensi periwayat (subjektif) baik secara redaksional (kecuali riwayat secara makna) maupun ketika penyebutan periwayat ( $r a>$ wi al-h\}adi $>$ th) dalam mata rantai sanad sebagai penjamin (grarantars) kebenaran materi h\}adi>th. Objektifitas (djeetivity) penilaian pernah dikemukakan 'Ali ibn al-Madini ketika ditanya tentang ayahnya dan dijawabnya, "Ini masalah agama. Ayah saya itu d\}a'i>f'. 25

Keima, prinsip berlaku umum (genealizability) yaitu sebuah konsep yang tergali dari suatu kasus yang bersifat spesifik tidak hanya berlaku untuk kasus itu tetapi juga berlaku untuk kasus lain yang sama. Kesimpulan hasil kritik mengandung pengertian yang bersifat umum, dalam arti dapat

${ }^{22}$ Ibid.

${ }^{23}$ Ibid., 263 juga al-D hahabi, Tadhkirah, 77.

${ }^{24}$ Alfred G uillame, Traditions of Isam(E dinburgh: Edinburgh University Press, 1987 M.), 83.

${ }^{25}$ Ibid. 
diaplikasikan pada kasus yang sama. Ini berarti ruang lingkup penerapan temuan-temuan hasil kritik dalam satu kaedah $\mathrm{h}$ \}adi>th tertentu dapat berlaku pada unit klasifikasi dan unit klasifikasi yang lain.

Jika kasus spesifik dijadikan sebagai sumber data kemudian ditarik generalisasi berupa kesimpulan, sementara kasus itu tidak dapat mewakili populasi yang ada di dalamnya, maka kesimpulan yang diperoleh tidak dapat diterima. G eneralisasi model ini pernah dilakukan oreintalis seperti Joseph Schacht dalam bukunya TheOrigns of MuhammadanJunispudenceketika mengemukakan teori prgjetingbadk bahwa h\}adi>th merupakan penisbahan pendapat para ahli fiqh abad II dan III Hijriyah kepada tokoh-tokoh terdahulu agar pendapat itu memiliki legitimasi dari orang-orang yang mempunyai otoritas lebih tinggi. ${ }^{26}$ Ketika mengemukakan data untuk mendukung teorinya itu, Schacht sebagaimana pendahulunya Goldziher menggunakan kejadian individual dan terbatas yang kemudian digeneralisasi dalam bentuk kesimpulan. Model yang digunakan Schacht ini tidak dapat diterima karena tidak representatif bagi seluruh populasi atau unit klasifikasi yang dikehendaki sehingga kesimpulan yang dibuat tidak relevan.

\section{Obyek Kritik $\mathrm{H}$ \}adi>th}

Tujuan kritik h \}adi>th adalah untuk menguji dan menganalisa secara kritis apakah secara historis dan material h\}adi>th dapat dibuktikan kebenarannya berasal dari Nabi atau tidak. D engan kata lain, tujuan utama kritik adalah untuk menilai apakah secara historis sesuatu yang dikatakan sebagai $h$ \}adi>th benar-benar dapat dipertanggungjawabkan kesahihannya berasal dari Nabi ataukah tidak. Hal ini, menurut M. Syuhudi Ismail, sangat penting mengingat kualitas $h$ \}adi>th erat sekali kaitannya dengan dapat atau tidak dapatnya dijadikan hujjah agama. ${ }^{27}$

Uji kebenaran (verifikasi) h\}adi>th difokuskan pada matan karena segala aktifitas kritik tidak lain dimaksudkan untuk mengetahui keotentikan matan itu. Hanya saja, dalam operasional kritik di kalangan ulama h\}adi>th, sanad menjadi objek utama penelitian. Fokus pada sanad ini, sebagaimana dikatakan Ibn Khaldun (w. 808 H./ 1406 M.), telah dilakukan ulama h\}adi>th ketika mereka meneliti berita dengan berpegang pada kritik terhadap pembawa berita itu (al-nma $>$ h). Hipotetisa yang dikemukakan adalah jika para pembawa berita (h\}adi>th) adalah orang-orang yang dapat dipercaya, maka beritanya dinyatakan valid dan sebaliknya, jika para pembawa berita itu bukan orang-orang terpercaya (tsicah), maka berita itu tidak dapat dijadikan hujjah agama.. ${ }^{28}$ D engan lain kata, kebenaran berita sangat tergantung pada 'kebenaran' pembawa berita itu.

Bahwa para ulama h \}adi>th lebih mendahulukan sanad sebagai objek kritik dikemukakan pula oleh Ahmad Amin dalam bukunya D \}uh\}a $>$ al-Isa $>$ m Ia menyatakan bahwa ulama h\}adi>th ketika melakukan kritik $\mathrm{h}$ \}adi>th lebih banyak menfokuskan pada kritik sanad daripada kritik matan. ${ }^{29} \mathrm{Amin}$ juga menyatakan dalam Fajr al-Isla>mbahwa para ulama lebih banyak menitikberatkan perhatian kepada studi kritik sanad (ekstern). Sedikit sekali ulama melontarkan kritik bahwa apa yang dinisbahkan kepada Nabi saw. sebenarnya tidak layak dan sesuai dengan situasi dan kondisi saat $h$ \}adi>th itu beliau kemukakan, atau realitas sejarah ternyata bertolak belakang dengannya, atau redaksi $\mathrm{h}$ \}adi>th itu sebenarnya tidak lebih dari pernyataan falsafi yang sama sekali tidak sejalan dengan redaksi yang

\footnotetext{
${ }^{26}$ Joseph Schacht, TheOrigins of MuhammadanJunispondence(O xford: Clarendon Press, 1975), 150.

${ }^{27}$ M. Syuhudi Ismail, Kaeckh Kesahihan SanadHadis(Jakarta : Bulan Bintang, 1995), .5

${ }^{28}$ Ibn K haldun, MuqaddimahilnKKhaldu>n(ttp: D a >r al-Fikr, tth.), 37.

${ }^{29}$ Ahmad Amin, D $\{$ uh\}a $>$ al-Ida>m(Kairo: Maktabah al-Nahd $\}$ ah al-Mis\}riyah, 1974 M.), 130-132.
} 
biasanya dipakai oleh Nabi saw. atau pola dan gaya pengungkapan h\}adi>th itu lebih mirip dengan pernyataan fiqh, dan sebagainya. ${ }^{30}$

Muhammad al-G hazali, seorang ulama Mesir kontemporer, mengikuti pendahulunya Muhammad Abu Rayyah, juga menyatakan bahwa kegiatan kritik $\mathrm{h}$ \}adi>th oleh para ahli h\}adi>th tercurah pada aspek sanad, sedang upaya meneliti matan $\mathrm{h}$ \}adi $>$ th justeru dilakukan oleh para fuqaha $>$ ' mijtahid $>\mathrm{n}^{31}$ Kegiatan kritik matan h\}adi>th oleh fucpha >' dikarenakan mereka berkepentingan untuk pencaharian landasan normatif penetapan hukum Islam. $\mathrm{H}$ \}adi>th sebagai sumber kedua setelah al-Q ur'a $>\mathrm{n}$, harus memenuhi kualifikasi tertentu untuk diterima sebagai dasar hujjah.

Jika diperhatikan prinsip-prinsip pengujian validitas dan akurasi $h$ \}adi>th dalam beberapa literatur ilmu $\mathrm{h}$ \}adi>th, kritik sanad memang menempati posisi lebih banyak terbukti dari lima kriteria deteksi $\mathrm{h}$ \}adi>th s\}ah\}i>h\}, hanya dua di antaranya yang berkait dengan sanad dan matan, tiga kriteria berkenaan dengan sanad saja. Meskipun dalam hal ini pendekatan kuantitatif tidak dapat dipergunakan untuk menentukan validitas penilaian. A sumsi dasar ulama $\mathrm{h}$ \}adi>th yang lebih menitikberatkan sanad sebagai tolok ukur menunjukkan bahwa kritik eksternal mendapat porsi yang lebih banyak dari pada kritik internal.

Kenyataan bahwa kritik sanad menempati porsi lebih banyak dalam penelitian dan kritik $\mathrm{h}\}$ adi $>$ th menunjukkan pula bahwa pendekatan historis (sejarah) dapat menjadi alternatif pengujian kebenaran (verifikasi) h \}adi>th. Sebagai deskripsi yang terpadu dari keadaan-keadaan atau fakta-fakta masa lampau, sejarah diharapkan dapat memberikan gambaran yang jelas dan benar tentang peristiwa masa silam itu. Kritik $\mathrm{h}$ \}adi>th dengan pendekatan historis merupakan penilaian dan penyelidikan kritis terhadap keberadaan $\mathrm{h}$ \}adi>th, pertumbuhan dan perkembangan periwayatan, dan pengalamanpengalaman yang terkait dengannya, serta menimbang dengan cukup teliti dan hati-hati tentang bukti validitas dari sumber informasi h\}adi>th (periwayat).

Hanya saja, dalam hal pencapaian validitas dan akurasi, kritik h\}adi>th dengan fokus sanad (kritik ekstern) semata tidak bisa dipertanggungjawabkan kebenarannya. D emikian pula, tuduhan bahwa ulama $\mathrm{h}$ \}adi>th telah melakukan usaha yang beldbihanberkenaan dengan al-jarh\} dan al-ta'di >l terhadap para periwayat $h$ \}adi>th, dengan menilai periwayat siqah atau tidak, menjelaskan kualitas ke-thiqahan mereka, meneliti apakah antar periwayat terjadi pertemuan atau tidak, dan dengan ukuran-ukuran seperti itu pula mereka mengklasifikasi h\}adi>th menjadi s\}ah\}i $>$ h\}, h\}asan, d\}ai $>$ f, musal, munat\}i', sh $>$ dh, ghan $>$ b dan lain-lain ${ }^{32}$ juga tidak bisa diterima. Tradisi epistemologis ulama $h$ \}adi $>$ th melalui 'ilmal-hadi $>$ th al-dira $>$ yah di samping 'ilmh\}ad $>$ th al-niwa $>$ yah menjadikan sanad dan matan sebagai fokus kritik $\mathrm{h}$ \}adi>th dan disusunnya beberapa istilah dalam ilmu h\}adi>th juga berkisar pada wilayah sanad dan matan itu.

Di samping itu, asumsi bahwa kritik eksternal merupakan fokus penelitian $\mathrm{h}$ \}adi>th telah menjadi sasaran empuk kritik kaum orientalis sepertiJoseph Schacht, Sprenger, dan G oldziher. Mereka menuduh sanad sebagai bikinan para ulama $\mathrm{h}$ \}adi>th dan tidak pernah ada pada zaman Nabi atau bahkan para sahabat. D engan kata lain, sistem isnâd menurut mereka, bersifat ahistoris D alam The Origns of

${ }^{30} \mathrm{~A}$ hmad Amin, Fajral-Isa>m(K airo: Maktabah al-Nahd\}ah al-Mis\}riyah, 1975 M.), 217-218.

${ }^{31}$ Muhammad al-G hazali, al-Sumnahal-Nabaniyah(Kairo: Da>r al-Shuru>q, 1989), 15.

${ }^{32}$ Lihat dalam: S $\{$ ala $>$ h al-Di $>$ n bin Ah\}mad al-Ad $\}$ abi, Manhaj, 5.

${ }^{33}$ Joseph Schacht, TheOrigins, 163. 
Muhammadan Junispudance, Joseph Schacht menyatakan bahwa bagian terbesar dari sanad $h$ \}adi>th adalah palsu. Semua orang mengetahui bahwa sanad pada mulanya muncul dalam bentuk yang sangat sederhana, kemudian mencapai tingkat kesempurnaannya pada paruh kedua abad ketiga Hijriyah. ${ }^{33}$ Ignaz Goldziher dalam bukunya Muhammedanische Studen menyatakan:

"When the rapid succession of conquest let them to distant countries, they handed on these h\}adi>th of the Prophet to those who had not heard them with their own ears, and after his death, they added many salutary sayings which were thought to be accord with his sentiments and could, therefore, in their view, legitimately be ascribed to him, or of whose soundness they were in general convinced". ${ }^{34}$

Berbeda dengan pendapat di atas, Mustafa al-Siba'i, Muhammad Abu Syuhbah, dan Nur al-Din 'Itr menyatakan bahwa ulama $\mathrm{h}$ \}adi>th tidak mengabaikan kritik matan $\mathrm{h}\}$ adi $>$ th, terbukti pada kaedah kesahihan $\mathrm{h}\}$ adi $>$ th dinyatakan sebagian syarat yang harus dipenuhi oleh $\mathrm{h}\}$ adi>th shahịhialah matan dan sanad h\}adi>th harus terhindar dari kejanggalan (al-sha $>$ dh) dan cacat (al-illah). ${ }^{35}$

Shalah al-D in ibn A hmad al-A dabi juga berpendapat, kritik matan yang tidak mencukupkan diri pada kritik sanad sebenarnya telah dikenal luas di kalangan sahabat dan generasi sesudahnya. Hanya saja, menurutnya, ada beberapa ulama semisal para teolog Mu'tazilah, yang menyebarkan asumsi bahwa ulama $\mathrm{h}$ \}adi>th hanya sekedar ibarat unta yang mengangkut barang (zawa $>$ mal-asfa $>\mathrm{r}$ ) yang tidak pernah merasa tertarik untuk mengadakan pemikiran dan penalaran. Para ahli h\}adi>th, menurut mereka, hanya bermaksud melakukan kritik sanad, tanpa memperhatikan sisi lain, yakni matan h\}adi>thnya. Lebih lanjut mereka beranggapan bahwa para ahli h\}adi>th jarang sekali menilik matan h\}adi>th, atau dengan kata lain, mereka hanya menerapkan sebagian kecil kaedah dan patokan kritik matan, bahkan telah melupakannya. ${ }^{36}$

Jika ditelusuri dalam literatur-literatur ilmu h \}adi>th, pendapat Muktazilah di atas tidak berdasar karena jika menggunakan pembuktian terbalik dengan melihat kriteria $h$ \}adi>th $d\} a i>f$ atau palsu, h\}adi>th-h \}adi>th dinyatakan d\}ai $>$ f atau palsu (mand\} $>$ ') lebih banyak ditentukan berdasar kriteria matan dari pada kriteria sanad. Ini terbukti, misalnya, dari sekitar 37 kriteria $h$ \}adi>th maud\} $>^{\prime}$ yang penulis kutip dari lima belas pendapat ulama, 29 di antaranya berkenaan dengan matan dan hanya 8 yang terkait dengan kriteria sanad. ${ }^{37}$ Ini menunjukkan, penggunaan kriteria sanad semata dalam kritik h\}adi>th kurang efektif.

D emikian halnya, fokus kritik h\}adi>th pada matan saja tidak dapat membawa pada hasil penelitian yang memadai kecuali dilakukan oleh para kritikus yang memenuhi kualifikasi seperti dijelaskan sebelumnya. Penekanan objek kritik pada matan semata berarti telah melakukan kesalahan dalam memahami h\}adi>th. Di kalangan ulama h\}adi>th, h\}adi>th bukan matan yang diriwayatkan dari Nabi saja. $\mathrm{H}$ \}adi>th adalah gabungan antara matan dan sanad.

Oleh sebab itu, menurut Muhammad Musthafa Azami, apabila terdapat matan h\}adi>th yang

\footnotetext{
${ }^{34}$ Ignaz G oldziher, MusimStudies vol 2 diterjemahkan dari bahasaJerman oleh C.R. Barber dan SM. Stern (London : G eorge Allen \& Unwin Ltd., 1971), 18 juga dalam John Burton, AnIntroduction, x.

${ }^{35} \mathrm{Nu}>\mathrm{r}$ al-D in 'Itr, Manha>j, 15-17, Must $\}$ afa $>$ al-Siba>'i>, al-Sumahwa Maka>natuha $>$ fi $>$ al-Tahri >' al-ISa>mi $>$ (Beirut: alMaktab al-Islami, 1985 M./ 1405 H.), 296-303, Muhammad Muhammad Abu Shuhbah, Difa ’' 'anal-Sumahwa RaddShubahalMustashriqi>nnaal-Kutta>bal-Mu'a>s\}ini>n(Kairo: Maktabah al-Azhar, tth.), 46-51.

${ }^{36}$ al-Ad \}abi, Manhaj, 4.

${ }^{37}$ Idri, KriteiaHadsMand\} w’ ddhllonal-Janzi (510-597H./ 1116-1200M)(Jakarta: Program Pascasarjana UIN Syarif Hidayatullah,
} 
sama, sementara ia memiliki sepuluh jalur sanad, maka para ahli h\}adi>th menghitungnya sepuluh h \}adi>th. Lagi pula, tidak setiap h \}adi>th mesti bersumber dari Nabi saw. sebab ucapan atau perbuatan sahabat juga dapat disebut $h$ \}adi>th, meskipun yang akhir ini memiliki sebutan lain, yaitu asar. ${ }^{38}$ Karenanya, objek kritik $\mathrm{h}$ \}adi>th mencakup dua aspek, yaitu aspek sanad dan matan. Ini menujukkan bahwa kritik $\mathrm{h}$ \}adi>th pada matan atau sanad semata kurang membawa pada pemerolehan hasil kritik yang akurat, valid, dan memadai.

\section{Urgensi Kritik $\mathrm{H}$ \}adi>th}

Kritik $\mathrm{h}$ \}adi>th penting dilakukan berdasar pertimbangan teologis, historis-dokumenter, praktis, dan pertimbangan teknis. Sebagai salah satu sumber otoritas ajaran Islam, h\}adi>th menempati posisi sentral. Sekiranya h \}adi>th Nabi hanya sebagai sejarah kehidupan Nabi (fiqhal-si>rah), niscaya perhatian para ahli terhadap transmisi $h$ \}adi>th berbeda dengan yang telah berlangsung dewasa ini. Beberapa ayat al-Q ur'a>n yang menjadi dasar argumentasi kehujjahan h \}adi>th Nabi dan keharusan mengikutinya ${ }^{39}$ menunjukkan bahwa mengikuti Nabi dan segala ajaran yang dibawa termasuk yang terekam dalam $\mathrm{h}$ \}adi>th merupakan suatu keniscayaan. Aspek teologis ini mendorong umat muslim dahulu hingga kini berupaya memelihara dan menjaga $\mathrm{h}$ \}adi>th dari kekeliruan dan pemalsuan. ${ }^{40}$

Kehadiran gerakan inkar al-sumah yang telah muncul semenjak zaman Imam al-Syafi'i (w. 204 H./ 820 M.) dan dengan gigih ia berusaha mematahkan argumentasi-argumentasi mereka ${ }^{41}$ merupakan bukti historis penolakan $\mathrm{h}$ \}adi>th dalam otoritas kesumberan Islam. Dalam hal ini, secara teologis h\}adi>th atau sunnah, yang pada masa al-Syafi'i berupa h\}adi>th ah\}âd dan pada masa berikutnya mencakup seluruh bentuk $\mathrm{h}$ \}adi>th, tidak diterima di kalangan inkar al-sumah sebagai sumber ajaran Islam kedua setelah al-Q ur'a $>$ n.

Di kalangan pemikir kontemporer, penolakan serupa juga terjadi. Tawfiq Sidqi dalam Majalah al-Manâr No. 7, 12 Tahun IX mengemukakan bahwa Islam tidak lain adalah al-Q ur'a>n sendiri, dan oleh karenanya tidak perlu h\}adi>th. ${ }^{42}$ Ismail A'zham berpendapat bahwa h\}adi>th-h\}adi>th yang ada sekarang - termasuk S\}ah\}i $>$ h\} al-Bukha $>\mathrm{r}>$ dan S\{ah\}i $>$ h\} Mudim- tidak dapat diandalkan keotentikannya dan tidak dapat dipercaya, bahkan kebanyakan palsu. ${ }^{43}$ Bagi mereka, di samping $h$ \}adi>th tidak mempunyai otoritas dalam kesumberan hukum Islam juga kritik terhadapnya dalam rangka untuk mengetahui keabsahannya tidak diperlukan lagi, karena kebanyakan $\mathrm{h}$ \}adi>th tidak dapat dipercaya. Tidak hanya $\mathrm{h}$ \}adi>th yang ah\}ad, $\mathrm{h}$ \}adi>th mtawa>tir yang diriwayatkan banyak orang dan oleh ulama h\}adi>th disebut mempunyai kekuatan uum $>$ dyang mantap (qat\}' $\mathrm{i}>$ al-wunu>d) sebagaimana halnya al-Q ur'a>n, oleh G hulam A hmad Parvez ditolak sebagai sumber otoritas Islam. ${ }^{44}$

Hampir sama dengan mereka, meskipun tidak sampai pada kualifikasi menolak eksistensi ataupun otoritas sunnah, Fazlurrahman mencoba menjelaskan posisi h\}adi>th atau sunnah dalam otoritas kesumberan hukum Islam dengan membaginya menjadi 'Sunnah yang Hidup' (the living Sunmah) yang

\footnotetext{
2004), 197.

${ }^{38}$ Azami, Studies, 301-313.

${ }^{39}$ Ayat dimaksud antara lain: (a) Surat Ali 'Imran : 32: Katakanlah: Taatilah Allah dan Rasul-Nya; jika kamu berpaling maka sesungguhrya Allah tidak menykai arangarangkafir.

${ }^{40} \mathrm{Ada}$ empat dasar argumentasi hadis sebagai sumber ajaran Islam, yaitu : (a) dalil al-Q ur'a>n, (b) hadis Nabi, (c) ijma' ulama, dan (d) argumentasi rasional. Lihat: Muhammad al-Khat\}i>b, Us\} $>1$, , 8-12.
} 
berasal dari tradisi kominitas muslim dan 'SunnahIdæal' berasal dari Nabi yang secara progresif ditafsirkan melalui ijtihad dan qiyas. ${ }^{45}$ D engan konsep ini, Rahman mengemukakan terjadinya evolusi sunnah yang memiliki kemiripan dengan teori 'prjetingbadk'nya Joseph Schacht dan karenanya ia oleh Maryam Jamilah dinilai sebagai penyerang otetisitas $h$ \}adi>th dan sunnah. ${ }^{46}$

Pertimbangan historis dan dokumenter bahwa mayoritas $\mathrm{h}$ \}adi>th tidak ditulis pada masa Nabi berbeda dengan al-Q ur'a $>n$ berakibat pada diragukannya sebagian $h$ \}adi $>$ th sebagai otentik dari Nabi.

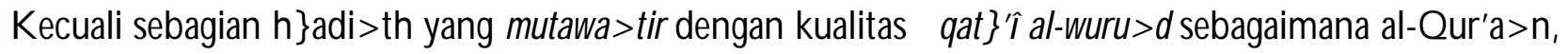
mayoritas $\mathrm{h}$ \}adi>th berada pada posisi $\mathrm{z}$ \}anni $>$ al-unu $>$ dkarena diriwayatkan secara ah\}ad ${ }^{47}$ Rentang waktu yang cukup panjang dari masa Nabi sampai zaman koodifikasi serta seleksi h\}adi>th selama tiga abad lebih memerlukan antisipasi tersendiri untuk mengetahui kualitas masing-masing $h$ \}adi>th. Kondisi ini dipersulit lagi dengan jumlah $\mathrm{h}$ \}adi>th yang sangat banyak dan tersebar di berbagai daerah serta diperparah oleh pihak-pihak tak bertanggungjawab yang memalsukan h\}adi>th.

Larangan Nabi menulis $h$ \}adi>th pada satu sisi, dikarenakan kekhawatiran tercampur dengan al-Q ur'a>n, dan pada sisi lain ia membolehkannya ${ }^{48}$ juga berakibat pada banyak $\mathrm{h}$ \}adi>th tidak ditulis dan seandainya Nabi tidak pernah melarangpun tidak mungkin seluruh h $\mathrm{h}$ adi>th dapat ditulis. Faktor penyebab tidak ditulisnya $\mathrm{h}$ \}adi>th pada masa Nabi, menurut M. Syuhudi Ismail adalah : [a] $\mathrm{h}$ \}adi>th disampaikan tidak selalu di hadapan sahabat yang pandai menulis h\}adi>th, [b] perhatian Nabi dan para sahabat lebih banyak tercurah pada al-Q ur'a $>n$, [c] meskipun Nabi mempunyai beberapa sekretaris tetapi mereka hanya diberi tugas menulis wahyu yang turun dan surat-surat nabi, [d] sangat sulit seluruh pernyataan, perbuatan, taqi $>$ r, dan hal ihwal orang yang masih hidup dapat langsung dicatat oleh orang lain apalagi dengan peralatan yang sangat sederhana. ${ }^{49}$

Meskipun ada beberapa sahabat yang mempunyai cacatan $h\}$ adi>th seperti 'Ali bin Abi $\mathrm{T}\{\mathrm{a}>\mathrm{lib}$ (w. 40 H./ 611 M.), Sumrah bin Jundab (w. 60 H./ 680 M.), 'Abd Allah bin 'Amr bin al-'Ash (w. 65 H./ 685 M.), 'Abd Allah bin 'Abbas (w. 69 H./ 689 M.), Jabir bin 'Abd Allah al-Anshari (w. 78 H./ 697 M.), dan 'Abd Allah bin Abi Awfa' (w. 86 H.), catatan mereka hanya sebagain dari sekian banyak h\}adi>th yang ada saat itu. D engan demikian, secara dokumenter, pada masa Nabi kebanyakan h $\mathrm{h}$ adi>th belum tertulis dan hanya diriwayatkan secara lisan. Sungguhpun demikian, pada masa sahabat catatan $\mathrm{h}$ \}adi>th semakin banyak. Penelitian Azami membuktikan bahwa tidak kurang dari 52 sahabat yang memiliki naskah-naskah catatan $\mathrm{h}$ \}adi $>$ th. D emikian pula tidak kurang dari 247 ta $>$ di'i $>$ n yang juga memiliki hal serupa. ${ }^{50}$

\footnotetext{
${ }^{41}$ Karena itu, al-Sha $>$ fi'i $>$ mendapat julukan sebagai pembela $h$ \}adi $>$ th (na $>$ s\}iral-h\}adi $>$ th) dan pembela sunnah (na $>$ s\}iralsumah mitazimal-sumah). Lihat: Muhammad Abu Zahrah, al-Sha $>$ fii $\mathrm{H}$ \{aya>tuhwa Ashuh: Ara>uhwaFiknuh(Beirut: D a $>\mathrm{r}$ al-Fikr, tth.), 214 juga 'Abd al-K arim al-Jundi, al-Ima>mal-Sha>fi'i > (K airo: D a>r al-Kutub al-'Arabi, 1967 M.), 295.

${ }^{42}$ Lihat: Muhammad Musthafa Azami, HadisNabawi danSgarah Kodifikasinya, terjemahan (Jakarta: Pustaka Firdaus, 2000 M.), 47.

${ }^{43}$ Ibid., 48.

${ }^{44}$ Lihat dalam : Syu'bah Asa, "Tamparan untuk Pengingkar Hadis", MajalahTempo Jakarta, edisi 16 A pril 1994 juga Fazlur Rahman, Some Islamic Issues in The Ayyub Khan Era, dalam D onald P. Little (ed.), EssaysonIsamicCivilization(Leiden : E.J. Brill, 1976 M.), 286.

${ }^{45}$ Fazlur Rahman, The Living Sunnah and al-Sunnah wa al-Jama'ah, dalam P.K. Koya (ed.), Hadith, 147-148.

${ }^{46}$ Maryam Jamilah, Idamdan Modemisme, terjemahan (Surabaya: al-Ikhlas, tth.), 129-133.

${ }^{47}$ Mahmud Abu Rayyah, Ad\}wa>' 'ala> al-Sunnahal-Muhammadyah(Mesir: Da>r al-Ma'arif, tth.), 280. juga Mahmud Syaltut, alIda>m'Aqi>dahwa Shari>'ah(K airo: D a>r al-Q alam, 1966), 65-67.

${ }^{48} \mathrm{H}$ \{adi>th yang melarang menulis hadis dan yang membolehkan dapat dilihat dalam : al-Bukhari, $\left.\mathrm{S}\{\mathrm{ah}\} \mathrm{i}>\mathrm{h}\right\}$ al-Bukha>ri>,
} 
Pemalsuan h $\mathrm{h}$ adi>th (thefabrication of hadiths) yang menurut jumhur ulama dimulai masa 'Ali bin Abi $\mathrm{T}\left\{\mathrm{a}>\mathrm{lib}^{51}\right.$ menambah keruwetan seleksi $\left.\mathrm{h}\right\}$ adi>th dan berdampak negatif bagi kehidupan umat muslim. Keberadaan $\mathrm{h}$ \}adi>th palsu telah mewarnai eksistensi $\mathrm{h}$ \}adi>th, yang pada satu sisi menyebabkan tidak semuanya autentik dan pada sisi lain berimplikasi pada berbagai bidang kehidupan baik secara langsung berkenaan dengan keagamaan maupun aktifitas kehidupan umumnya. Secara praktis, kontaminasi h\}adi>th Nabi oleh $\mathrm{h}$ \}adi>th-h \}adi>th palsu mempersulit umat muslim untuk beramal secara benar berdasar ajaran Nabi yang benar pula. $\mathrm{H}$ \}adi>th mand\} $\triangleright^{\prime}$ ' berimplikasi negatif bagi umat muslim karena dapat memalingkan mereka dari jalan yang lurus pada kesesatan. Para pemalsu h \}adi>th telah melakukan kejahatan terhadap agama Islam, dengan kedustaan mereka mencoreng harkat dan martabatnya. ${ }^{52}$ Ini terutama terlihat pada ulah kaum Zindik yang sengaja membuat $h$ \}adi>th$\mathrm{h}$ \}adi>th palsu dengan motivasi untuk merusak Islam dari dalam. ${ }^{53}$

Tidak sedikit h\}adi>th yang mereka buat dapat meluluhlantakkan fondasi-fondasi Islam sehingga bila tidak dilakukan koreksi, klarifikasi dan koleksi, dapat berakibat pada kehancuran ajaran Islam. Di samping itu, sebagian $\mathrm{h}$ \}adi>th palsu yang dibuat dengan maksud mendapatkan justifikasi politik, aliran keagamaan, chauvinisme atau primordialisme dapat mengancam kehidupan beragama umat muslim, ${ }^{54}$ terjadinya perpecahan di antara mereka, dan merupakan musibah besar yang berdampak negatif pada banyak hal baik bidang akidah maupun shari $>$ 'ah. ${ }^{55}$ Karena itu, para ulama melarang keras pembuatan dan periwayatan $\mathrm{h}\}$ adi>th palsu kecuali disertai penjelasan identitas kepalsuannya. ${ }^{56}$

Fenomena pemalsuan $\mathrm{h}\}$ adi $>$ th dalam perspektif ulama $\mathrm{h}$ \}adi>th sebagai dijelaskan di atas sehingga mendorong kodifikasi $\mathrm{h}$ \}adi>th masa 'Umar ibn 'Abd al-'Aziz - berbeda dengan perspektif para orientalis tentang topik yang sama. Para orientalis yang diwakili oleh Ignaz Goldziher, ${ }^{57}$ Margoliouth, ${ }^{58} \mathrm{H}$. Lammens, ${ }^{59}$ dan Joseph Schacht ${ }^{60}$ menyatakan bahwa mayoritas atau bahkan keseluruhan $\mathrm{h}$ \}adi>th tidak berasal dari Nabi. Mereka mengemukakan thesis tentang penolakan otoritas sunnah sebagai sumber ajaran Islam yang otentik dari Nabi. D engan kata lain, menurut mereka, sebagian besar atau bahkan semua h\}adi>th Nabi palsu. Sebagaimana bagi kelompok inkar al-sumah bagi para orientalis teori-teori kritik $\mathrm{h}$ \}adi>th yang dikemukakan ulama $\mathrm{h}$ \}adi>th tidak siginifikan untuk menguji otentisitas h \}adi>th Nabi.

Pendekatan para orientalis di atas tidak relevan karena kerangka pikir mereka bertolakbelakang dengan kerangka pikir ahli $\mathrm{h}$ \}adi>th. Mereka menolak eksistensi dan otentisitas $\mathrm{h}$ \}adi>th dalam perspektif yang berlawanan dengan konsep dan teori-teori ahli $h$ \}adi>th muslim yang telah mentradisi sejak jaman klasik hingga sekarang. Karena itu, para ahli h\}adi>th kontemporer menyanggah dan menolak thesis mereka itu, antara lain Mustafa Azami dalam buku yang berasal dari disertasi doktornya di Universitas Cambridge Inggris, Studes in Early Hadith Literature wih A Critical Edition of SomeEarly juz I (Beirut: Da>r al-Fikr, tth.), 32, Muslim bin al-Hajjaj, S\{ah\}i>h\} Musim juz II (Beirut: Da>r al-Fikr, tth.), 988, Abu D awud al-Sijiztani, SunanAbi> Da>wu>d, juz III (Beirut: D a >r al-Fikr, tth.), 318-319, juz IV, 172, A hmad bin Hanbal, Musnad Ah\}madbinH \{anbal, juz III (Beirut: al-Maktab al-Islami, 1978 M.), 12, 21, 39.

${ }^{49}$ M. Suhudi Ismail, Kaedah 101-102.

${ }^{50}$ Muhammad Musthafa Azami, Studies, 34-182.

${ }^{51} a l-K$ hatib, al-Summah, 182, pengarang yang sama, Us\}u>l, 415-416, Mus\}t\}afa> al-Siba>'i >, al-Sumnah, 75, S\{ubh\}i alS $\{$ a $>$ lih, Ulu>mal-H \{adi >thwaMus\}t\}alahuh (Beirut: D a $>$ r al-'Ilm li al-Malayin, 1988 M), 266, dan Muhammad Muhammad Abu Zahw, al-H[adi>thwaal-Muh\}addithu>n(Beirut: Da>r al-Kutub al-'Arabi, 1984 M.), 114.

${ }^{52}$ al-K hatib, al-Sumnah 219.

${ }^{53}$ Mustafa al-Siba>'i>, al-Sumnah 83.

${ }^{54}$ al-Khatib, Us\}u>l, 420-427 dan Must\}afa> al-Siba> 'i > , al-Sumnah 79-88. 
Text. Sebelumnya, Mustafa al-Siba'i tahun 1949 juga menolak pendapat-pendapat mereka dalam bukunya al-Sumah wa Maka>natuha $>$ fi $>$ al-Tashri >' al-Isa>m> pada bab keenam berjudul al-Sunnah máa alMushtashiqi>n Tahun 1956, Muhammad 'Ajjaj al-Khatib menulis kitab al-Sunnah qabl al-Tadwi>n terutama bab tiga sub bab tiga dengan judul : Ara >' al-Mushtashriqi>n waAshya>'ihimfi> al-Sumah wa Naqdiha $>$ yang menolak pendapat para orientalis di atas.

Proses kodifikasi h\}adi>th yang dimulai semenjak masa 'Umar bin 'Abd al-'Aziz (99-101 H.) dan memakan interval waktu cukup lama juga menuntut kritik $\mathrm{h}$ \}adi>th untuk penelusuran keotentikannya. Musthafa al-Siba'i mengemukkan tenggang waktu pembukuan h\}adi>th itu semenjak masa 'Umar sampai masa al-Nasa'i (w. 303 H.) yang memakan waktu sekitar 200 tahun atau tepatnya 205 tahun. ${ }^{61}$

Rentang waktu yang cukup panjang itu memberi peluang pada munculnya kesulitan untuk menyeleksi h \}adi>th-h\}adi>th antara yang sah dan tidak. Bahkan, Harun Nasution menyatakan bahwa karena $\mathrm{h}$ \}adi>th tidak dihafal dan tidak dicatat sejak semula, tidaklah dapat diketahui dengan pasti mana $h$ \}adi>th yang betul-betul berasal dari Nabi dan mana h\}adi>th yang dibuat-buat. Selanjutnya, Harun mengemukakan bahwa dalam rentang waktu yang panjang h\}adi>th yang dikatakan berasal dari Nabi bertambah banyak sehingga bertambah sulit pula untuk membedakan $\mathrm{h}$ \}adi>th yang orisinil dan yang dibuat-buat. ${ }^{62}$ Meskipun pendapat Harun ini perlu dicermati ulang dan dibantah oleh M. Rasyidi, ${ }^{63}$ realita bahwa penulisan dan pembukuan $\mathrm{h}$ \}adi>th telah memakan waktu yang cukup lama tidak bisa dipungkiri. Kondisi ini menuntut adanya kritik h\}adi>th.

Secara teknik, penyaduran $\mathrm{h}\}$ adi $>$ th di mana sebagian $\mathrm{h}\}$ adi>th diriwayatkan secara makna (alnima>yah bi alma'ma>) dan sebagian lain secara lafal (al-niva>yah bi al-lafz\}), sebagian kalimat disingkat (al-ikhtis\}a $>$ r), penambahan kata penjelas kalimat (al-ziya $>$ dah), penambahan sisipan (al-idra $>j$ ), penggunaan kata sinonim, penggunaan kata yang mirip secara literal, dan sebagainya serta pengeditan h\}adi>th yang berbaur dengan fatwa sahabat dan ta $>$ bi'i $>$ nmemerlukan kritik ulang tentang kualitas dan status $\mathrm{h}$ \}adi>th-h \}adi>th itu. D emikian pula diragukannya sebagian $\mathrm{h}$ \}adi>th karena secara teknis tidak memenuhi tingkat akurasi dalam pengutipan dan penulisan baik dikarenakan keterbatasan intelektualitas periwayat, kekurang-cermatan, dan sebagainya atau adanya tradisi pengutipan matan $\mathrm{h}\}$ adi>th tanpa dilengkapi dengan sanadnya.

\section{Standarisasi Kritik H \}adi>th}

Diskursus yang mengemuka dalam persoalan kritik $\mathrm{h}$ \}adi>th adalah banyaknya periwayat yang terlibat, banyaknya nama periwayat yang sama, rentang waktu yang panjang antara periwayat pertama hingga periwayat terakhir, banyaknya mata rantai periwayat, metode penilaian yang berbeda, dan lain-

\footnotetext{
${ }^{55}$ al-Q asimi, Qawa>'id, 153 juga al-Albani, Silsilatal-Ah\}a>di>thal-D \{a>ifahwaal-Mawd\}u>'ahwaAthanuha> al-Sai' fi>alUmmah, juz I (Beirut: al-Maktab al-Islami, 1985 M.), 10.

${ }^{56}$ al-'Iraqi, al-Taqji>dwaal-I<d\}ah (Madinah: al-Maktabah al-Salafiyah, 1969 M.), 130-131.

${ }^{57}$ Ignaz Goldziher, MusimStudies 18-19.

${ }^{58}$ Fazlurrahman, Idam(Chicago : University of Chicago Press, 1979 M.), 45.

${ }^{59} \mathrm{H}$. Lammens, Idam: BdiekesandInstitutions(London : Frank Cass \& Co, 1968), 69.

${ }^{60}$ Joseph Schacht, TheOrigin, 3.

${ }^{61}$ M. Erfan Soebahar, Mengrak FaktaKeabsahanal-Sunnah(Jakarta: Kencana, 2003 M.), 165.

${ }^{62}$ Harun Nasution, IsamDitinjau dari Bedbagai Aspknna, jilid I (Jakarta: UI Press, 1985 M.), $28-29$.

${ }^{63}$ M. Rasyidi, Karksi tehadapHanunNasution(Jakarta: Bulan Bintang, 1977 M.), 29-30.
} 
lain. Tidak kalah pentingnya persoalan sejauhmana informasi dapat menggambarkan keberadaan periwayat dan kritikusnya secara jelas, dilihat dari segi sosio-kultural, hubungan kritikus dengan periwayat, spesialisasi, dan parameter serta metode yang dipakai dalam penilaian.

Terlalu banyaknya periwayat yang dinilai dan dikritik memunculkan persoalan; mungkinkah dapat diketahui dengan akurat puluhan bahkan ratusan ribu orang periwayat dengan data pribadi masingmasing; lahir, mati, lingkungan, keluarga, pendidikan, guru dan murid, kecerdasan, kepribadian, dan sebagainya. Penilaian yang tidak hanya oleh teman sejawat atau sezaman dengan kritikus tetapi juga kepada periwayat terdahulu juga memerlukan keahlian dan ketekunan tersendiri.

Di samping itu, sejalan dengan perkembangan ilmu pengetahuan di kalangan umat muslim baik rumpun ilmu keislaman seperti ilmu kalam, tafsir, fiqh, dan us\}ul al-fiqh maupun ilmu umum seperti filsafat, kedokteran, dan kimia, kajian kritik $\mathrm{h}$ \}adi>th terus dikembangkan dengan berpegang pada kaedah-kaedah, metode-metode, dan teori-teori kritik, maupun hal-hal lain yang terkait. Dasar-dasar kritik h \}adi>th yang dalam bentuk sederhana dicanangkan oleh Muhammad bin Shihab al-Zuhri (51124 H.), dikembangkan oleh para ulama abad kedua, ketiga Hijriyah, dan seterusnya sehingga mengalami penyempurnaan baik dalam bentuk, teori, kriteria, maupun strukturnya. ${ }^{64}$

Keterlibatan para imam madzhab fiqh dalam diskursus kritik h\}adi>th ditambah dengan karya monomental para kolektor (al-mudawin) h\}adi>th seperti al-Bukhari, Muslim, Abu D awud, alTurmudzi, dan Ibn Majah secara langsung ataupun tidak telah berpengaruh positif pada pengembangan teori-teori kritik $\mathrm{h}$ \}adi>th. Melalui komentar-komentar mereka ketika memaparkan h\}adi>th dalam karya-karya mereka telah ditarik dan dibuat kaedah-kaedah serta teori-teori kritik h\}adi>th. Meskipun tidak secara langsung bermaksud menyeleksi kualitas $\mathrm{h}$ \} adi>th untuk kepentingan $\mathrm{h}$ \}adi $>$ th itu sendiri tetapi lebih untuk menggali muatan hukum $\mathrm{h}$ \}adi>th (istinbat\} al-h\}ukm), para fuqaha $>$ ' juga telah memberikan andil yang cukup besar dalam pengembangan teori-teori kritik $\mathrm{h}$ \}adi>th.

Kajian kritik $\mathrm{h}$ \}adi>th dalam khazanah literatur baik kritik sanad maupun matan baru dilakukan pada pertengahan abad keempat Hijriyah. Sejak abad ini telaah epistemologis kritik h \}adi>th dikembangkan dan terstandarkan sebagai salah satu bentuk ilmu h\}adi>th. Secara garis besar, kajian kritik dalam bidang ini dapat diklasifikasi menjadi dua. Petama, kajian kritik h\}adi>th bersamaan dengan $\mathrm{l} l m u \mathrm{~h}$ \}adi>th lain. Umumnya kajian kritik yang terintegrasi dengan cabang ilmu h $\mathrm{h}$ adi>th lain terdapat dalam literatur-literatur ilmu h\}adi>th. Misalnya, dalam kitab Ma'nifah Ulûm al-Hadis karya al-Hakim al-Naysaburi (321-405 H.), al-Kifa>yah fi> Qava>ni>n al-Riwa>yah dan al-Ja>mi' li Ada>b al-Shaykh wa al-Sa>mi' oleh al-Khat $\}$ ib al-Baghdadi (w. 463 H.), 'Ulu>mal-H $\{$ ad $>$ th yang dikenal dengan Mucaddimah Iln al-S\{ala>h oleh Ibn al-S\{ala>h (w. 643 H.), Manz\}u $>$ mah Tlm al-Atha $>r$ karya al-Suyut\}i $>$ (w. 911 H.) yang kemudian disharah oleh al-Tirmisi lewat karyanya Manhaj Dhawi> al-Naz $\} a>$, Tadi $>$ b al-Ra $>$ wi $>$ juga karya al-Suyuti sherah atas kitab al-Taqi $>b$ wa al-Tays $>r$ karya al-Nawawi (w. 676 H.), Naz\}mal-Dura $>$ r fi $>$ Tlmal-A tha $>$ r karya al-'Iraqi (w. 806 H.), Nuhbat al-Fikr fi Mus\}t\} alat Ahl al-Atha $>$ r karya Ibn Hajar al-'A sqalani, al-Mughi>sfi> SharhAlfiyat al-H \{adi>th karya al-Sakhawi (w. 902 H.), dan Qawa>'id al-Taks\}i>s\} karya al-Q a>simi (w. 1332 H.).

Keedua, kritik h\}adi>th dalam disiplin ilmu tersendiri, yaitu ilmu al-jarh\} wa al-ta'di >l. Literatur

\footnotetext{
${ }^{64}$ al-Tirmisi, Marha $>$ jDhawi>al-Naz\}a $>$ r (Beirut: D a $>$ r al-Fikr, 1981), 205.

${ }^{65}$ Bandingkan dengan Suryadi, Metoddog IlmuRijalil Hadis(Jogyakarta: Madani Pustaka, 2003), 68-80.

${ }^{66} \mathrm{Abu}$ Hatim al-Razi, Kitabal-Jarh\} waal-Ta'dil, juz II (Hederabad: Majlis D a>irat al-Ma'arif, 1952 M.), 3.7
} 
h\}adi>th yang terkait dengan disipilin ini dimulai sejak abad ketiga dan memuat biografi para periwayat dan sebagian h\}adi>th yang mereka riwayatkan, dapat diklasifikasi menjadi empat kategori:

1] Kategori t\}abaqa $>t$, yaitu para periwayat $h\}$ adi $>$ th yang memiliki kesamaan dalam setiap tingkatannya. Kategori kitab ini terbagi dua; ada yang berisi tabacat periwayat secara umum seperti al-T abaca>t al-Kubra> karya al-Waqidi (w. 230 H.) dan ada pula tentang periwayat secara khusus seperti Tadkkirat al-Huffaz\} karya al-D hahabi yang memuat 1.176 periwayat.

2] Kategori periwayat secara umum berisi para periwayat dalam berbagai kitab $\mathrm{h}$ \}adi>th dengan kualitas beragam baik yang siqah maupun tidak, seperti kitab al-Ta $>\mathrm{n}>\mathrm{kh}$ al-Kabi $>\mathrm{r}$ karya al-Bukhari yang memuat 12.305 periwayat dan kitab al-Jarh\} wa al-Ta'di >l karya Abu Hatim al-Razi.

3] Kategori periwayat dalam kitab tertentu, dipaparkan secara ringkas seperti al-Hida>yahwa al-Irsha $>d$ fi> Márifat Ahl al-Thicah wa al-Sa>da>t oleh al-Kalabadhi (w. 309 H.) berisi para periwayat kitab $\mathrm{S}\{a \mathrm{ah}\} \mathrm{i}>\mathrm{h}\}$ al-Bukha $>\mathrm{r}>$, Rija $>\mathrm{l}$ S $\{\mathrm{ah}\} \mathrm{i}>\mathrm{h}\}$ Musimditulis oleh al-A sfahani (w. $428 \mathrm{H}$.), al-Jam bayn Rija>l al-S\{ah\}i>h\}ayn karya al-Maqdisi (w. 507 H.), dan al-Ta'n>f bi al-Rija>l al-Munat\}t\}a” oleh al-Tamimi (w. 416 H.).

4] Kategori periwayat thiqah dan d\{ai $>$ f, terbagi menjadi dua : (a) Periwayat thiqph seperti kitab alThiqa>t karya al-'Ijli (w. 261 H.), kitab al-Thiqa>t oleh al-Busti (w. 354 H.), dan Ta>ri>kh Asma>' al-Thiqa>t min Man Nuqil 'anhumal-Tlmoleh 'Umar bin Shahin (w. 385 H.). (b) Periwayat d\}aî̀f seperti kitab al-D \{ưafa>' al-Kabi>r dan al-D \{ưafa>' al-S aghi>r karya al-Bukhari, al-D \{ưafa>' wa al-Matru>ku>n karya dan Nasa'i, Kita>b al-D \{u'afa>' wa al-Matru>ki>n oleh Ibn al-Jawzi (510597 H.), al-D \{ưafa>' oleh al-'Uqayli (w. 323 H.), Mánifah al-Majnu>hi>n min al-Muhaddthi>n oleh Ibn Hibban (w. 394 H.), dan al-Ka>mil fi > D \{u'afa>' al-Rija>l karya Ibn 'Adi (w. 356 H.). ${ }^{65}$

Klasifikasi dalam empat model kategori di atas lebih banyak bersifat deskriptif berupa pemaparan narasi-biografis para periwayat $h$ \}adi>th dengan aspek-aspek spesifik; nama lengkap, guru dan murid, tahun lahir dan wafat, kritik ulama, contoh $\mathrm{h}$ \}adi>th yang diriwayatkan, dan sebagainya. Berhubung kritik h\}adi>th menyangkut persoalan lampau sehingga tidak dapat dilakukan secara ahistars, maka beberapa literatur di atas sangat membantu dalam memberikan informasi tentang keberadaan para periwayat $\mathrm{h}$ \}adi>th. Hanya saja, ketika dilakukan kritik dan penelitian $\mathrm{h}$ \}adi>th berdasar data dalam literatur-literatur di atas, untuk mencapai tingkat akurasi yang memadai dewasa ini bukan hal mudah. Kesulitan yang dihadapi disebabkan antara lain oleh:

1] Sebagian data tentang periwayat tidak disertai dengan informasi yang lengkap tentang biografi periwayat yang dinilai/ dikritik.

2] Adanya penisbahan penilaian pada kritikus lain, bahkan yang tidak semasa, yang sering tanpa penjelasan persambungan periwayatannya.

3] Adanya penilaian tanpa disertai argumen yang jelas, mengapa mengkritik periwayat baik kritik negatif maupun positif.

4] Adanya fenomena kritikus melakukan penilaian terhadap berpuluh bahkan beratus ribu periwayat yang tentu perlu dipertanyakan tingkat akurasi penilaiannya.

5] Adanya perbedaan dalam penggunaan istilah (redaksi) kritik tertentu oleh satu kritikus dengan kritikus yang lain.

${ }^{67}$ Ibn al-S\{ala>h, Muqaddimah 110-111. 
6] Adanya perbedaan sikap kritikus periwayat dalam melakukan kritik, yaitu kritikus yang ketat (almatasyadid), sedang (al-mitawassit\}), dan longgar (al-mtasahil).

7] Adanya kecenderungan untuk melakukan kutipan, peringkasan, dan penyempurnaan terhadap kitabkitab al-Jarh\} wa al-Ta'di>l yang telah ada sebelumnya.

Secara teoritik, para ulama telah menentukan istilah (redaksi) kritik sebagaimana disebut pada nomor [5] di atas dengan jumlah, bentuk, dan urutan yang beragam. Data dalam beberapa literatur ilmu h \}adi>th menunjukkan belum adanya kesepakatan tentang redaksi kritik bahkan ada kecenderungan terjadi pergeseran dari satu generasi pada generasi berikutnya. Ini terlihat pada redaksi kritik yang dikemukakan Ibn Abi Hatim al-Razi (w.327 H.), ${ }^{66}$ Ibn al-S\{alah (w. 643 H./ 1245 M.) ${ }^{67}$ dan al-Nawawi (w. 676 H./ 1277 M. ${ }^{68}$ sekitar abad ketujuh Hijriyah memiliki banyak persamaan dengan sedikit perbedaan pada peringkat pertama. Ketiga ulama ini membagi peringkat kritik positif menjadi empat. Pada abad berikutnya sekitar abad delapan dan sembilan Hijriyah, al-D zahabi (748 H./ 1348 M.), ${ }^{69}$ al'Iraqi (w. 806 H./ 1404 M.), ${ }^{70}$ dan al-Harawi (w. 837 H./ 1436 M.), ${ }^{71}$ meskipun masing-masing menyebut lima peringkat tetapi terdapat perbedaan siginifikan baik pada peringkat pertama, kedua, ketiga, keempat, maupun kelima. Sementara Ibn Hajar al-'Asqalani (w. 852 H./ 1447 M.) ${ }^{72}$ dan al-Suyuti (w. 911 H./ 1505 M.) $)^{73}$ yang hidup pada abad sembilan dan sepuluh membaginya menjadi enam peringkat dengan redaksi lebih lengkap dan beragam.

Ada beberapa kemungkinan sehingga terjadi perbedaan ulama dalam menentukan bentuk dan peringkat redaksi kritik $\mathrm{h}\}$ adi>th sebagai berikut :

1] Telah terjadi perkembangan dan penambahan istilah yang digunakan para kritikus periwayat dari masa ke masa.

2] Para kritikus periwayat menggunakan istilah-istilah yang cukup banyak, tetapi sebagian ulama hanya menyebutkan sebagiannya saja sebagai contoh (sampel).

3] Sebagian kritikus periwayat menggunakan redaksi yang terbatas dan lebih sedikit dari kritikus periwayat lain.

4] Sebagian ulama mengikuti ulama sebelumnya dalam menetapkan peringkat kritik $\mathrm{h}$ \}adi>th sehingga hasilnya sama.

5] Jumlah sampel yang digunakan untuk membuat peringkat redaksi berbeda yang berakibat pada hasil yang berbeda pula.

Standarisasi ilmu kritik $\mathrm{h}$ \}adi>th dapat dilakukan dengan menerapkan tiga prinsip ilmiah berikut : (a) memiliki dasar pembenaran, (b) bersifat sistematik, dan (c) bersifat inter-subjektif. ${ }^{74}$ Memiliki dasar pembenaran maksudnya aktifitas kritik $\mathrm{h}$ \}adi>th harus memiliki seperangkat aturan tata kerja ilmiah yang diarahkan untuk mendapatkan derajad kebenaran setinggi mungkin sehingga terbuka peluang verifikasi dan pembenaran isi kritik tersebut. Bersifat sistematik maksudnya adalah adanya sistem dalam struktur kritik dan cara pelaksanaannya. Aktifitas kritik tidak membatasi diri pada satu informasi, tetapi senantiasa meletakkan hubungan antar sejumlah in-put yang ada dalam satu kebulatan dengan cara komparasi, subsumasi, dan generalisasi. Diupayakan kritik dilakukan melalui tahapantahapan yang sistematik, analitik, dan interpretatif. Kritik h\}adi>th dilakukan secara inter-subjektif maksudnya kepastian kebenaran hasil kritik tidak didasarkan atas pendapat kritikus perseorangan semata,

${ }^{68}$ al-Nawawi, al-Taqi>bli al-Nawa>wi> (Kairo: 'Abd al-Rahman Muhammad, tth.), 14. 
tetapi jika memungkinkan didukung oleh pendapat kritikus-kritikus h \}adi>th yang lain.

\section{Penutup}

Pada akhir tulisan ini hal yang perlu disampaikan adalah bahwa kritik $\mathrm{h}$ \}adi>th dalam perspektif kontemporer mengalami perbedaan dengan kritik h \}adi>th masa klasik. Pengaruh pemikiran modern, termasuk dari kalangan orientalis terasa pada sebagian pemikiran $\mathrm{h}$ \}adi>th kontemporer, meskipun kemudian disanggah oleh para ahli h\}adi>th dewasa ini. Penegasan kembali landasan kognitif kritik $\mathrm{h}$ \}adi>th diperlukan mengingat studi $\mathrm{h}$ \}adi>th kontemporer tidak hanya berkutat pada wilayah keilmuan keislaman, khususnya ilmu h\}adi>th, tetapi menggunakan pendekatan ilmu lain seperti sejarah, sosial, dan filsafat (hermenetik).

Karena itu, aplikasi prinsip-prinsip ilmiah dalam kritik $\mathrm{h}$ \}adi>th kontemporer merupakan hal esensial untuk mendapatkan hasil kritik yang valid dan memadai. Diharapkan dengan menggunakan prinsip itu, validitas dan realibilitas hasil kritik dapat tercapai. D emikian halnya standarisasi kritik h\}adi>th yang telah dikemukakan ulama klasik dalam ilmu al-jarh\} wa al-tádil di samping dapat digunakan sebagai landasan epistemologis kritik dan penelitian h \}adi>th juga dapat disesuaikan dengan prinsip-prinsip ilmiah umumnya.

\section{Daftar Rujukan:}

al-Ad\}abi, S\{ala>h al-Di>n bin Ahmad. Manhaj Naqd al-Matn 'ind 'Ulama' al-H \{adi>th al-Nabami>. Beirut: Da>r al-Afla>q al-Jadidah, 1983 M.

Amin, Ahmad. D \{uha> al-Isla>m Kairo: Maktabah al-Nahd\}ah al-Mis\}riyah, 1974 M. - - - - - . Fajr al-Isla>m Kairo: Maktabah al-Nahd\}ah al-Mis\}riyah, 1975 M.

al-Albani. Silsilah al-Ah\}a $>$ di $>$ th al-D \{a'ifah wa al-Mamd\}u $>$ 'ah wa Athanuha $>$ al-Sayyi' fi $>$ al-Ummah Beirut: al-Maktab al-Islami, $1985 \mathrm{M}$.

al-Asqalani, Ibn Hajar. Fath\} al-Ba>ri $>$ Sharh\} S\{ah\}i $>$ h\} al-Bukha $>$ i $>$. Beirut: D a $>$ r al-Fikr, tt. - - - - - Lisa>n al-Miza>n Beirut: Da>r al-Kutub al-'Ilmi>yah, 1416 H./ 1996 M.

- - - - - Nuzhat al-Naz\}a $>$ r Sharh\} Nukhbat al-Fika $>$ r. Semarang: Maktabah al-Munawwar, tt. - - - - . Sharh\} Nuhbat al-Fikr fi> Mus\}t\}alah\} Ahl al-Atha>r. Beirut: Da>r al-Assar, 1984 M. - - - - . Tahdhi >b al-Tahdhi>b Beirut: D a>r al-Kutub al-'Tlmiyah, 1987 M.

Azami, Muhammad Mus\}t\}afa>, Marhaj al-Naqd 'ind al-Munaddthi>n Riyad\}: al-Ummariyah, 1982 M. - - - - . H\}adi $>$ th Nabawi dan Sejarah Kodifikasinya, terjemahan. Jakarta: Pustaka Firdaus, 2000 M.

\footnotetext{
${ }^{69}$ al-D hahabi, Mi>za>n, 4,

${ }^{70}$ al-'Iraqi, al-Taqui $>$ d, 157-164.

${ }^{71}$ al-Harawi, Java>hiral-Us\{u>l fi> 'TlmH \{adi>thal-Rasu>l (al-Madinah al-Munawwarah: al-Maktabah al-'Ilmiyah, 1373 H.), 60-61.

${ }^{72}$ Ibn Hajar al-'Asqalani, Nuzhatal-Naz\}a>r, 66-67.

${ }^{73}$ al-Suyuti, Tadi> $>$ juz I, 342-350.

${ }^{74}$ Beerling. D kk., Pengantar Filsafat Ilmu, terjemahan (Yogyakarta: Tiara Wacana, 2001 M.), 6.
} 
- - - - - . Studes in Hadith Metoddogy and Literature Indianapolis: IslamicTeaching Center, 1977 M. Burton, John. AnIntroduction totheHadth Edinburgh: Edinburgh University Press, tt. Beerling. D kk. Pengantar Filsafat Ilmu terjemahan. Yogyakarta: Tiara Wacana, 2001 M.

D epartemen Pendidikan dan Kebudayaan. Kams UmmBahasa Indonesia Jakarta, Balai Pustaka, 1988 M.

D onald P. Little (ed.). Essays on Islamic Civilization Leiden: E.J. Brill, 1976 M. al-D hahabi, Mi>za>n al-T'tida>l fi> Naqd al-Rija>l. Beirut: D a>r al-Kutub al-'Ilmi>yah, $1995 \mathrm{M}$. - - - - - Tadkkirah al-Huffa>z., Heiderabad: The D airat el-Maarif el-O thmaniya, 1955 M.

Fallatah, 'Umar bin Hasan 'Uthma>n. al-Wad\}' fi > al-H $\{$ adi >th Beirut: Muassasah Manahil al-'Irfan, $1981 \mathrm{M} / 1401 \mathrm{H}$.

Fazlurrahman. Isam Chicago: University of Chicago Press, 1979 M.

al-Ghazali, Muhammad. al-Sumah al-Nabaniyah Kairo: D a>r al-Shuru>q, 1989 M.

Goldziher, Ignaz. MusimStudies London: G eorge Allen \& Unwin Ltd., 1971 M.

G uillame, Alfred. Traditions of Islam Edinburgh: Edinburgh University Press, 1987 M.

al-Harawi. Jawa $>$ hir al-Us\}ul $>$ fi> 'Ilm H \{adi>th al-Rasu>l. al-Madinah al-Munawwarah: al-Maktabah al-'Ilmiyah, $1373 \mathrm{H}$.

Idri. Kriteia H\}adi>th Mand\}u>" deh Ibn al-Janzi (510-597 H./ 1116-1200 M). Jakarta: Program Pascasarjana UIN Syarif Hidayatullah, 2004 M.

al-Iraqi, al-Taqui $>$ d wa al-I $<$ d\}a $>$ h Madinah: al-Maktabah al-Salafiyah, 1969 M.

Ismail, M. Syhudi. Kaedah Kesahihan Sanad H\}ad>th Jakarta: Bulan Bintang, 1995 M.

- - - - . Metoddog Penditian H\}adi>th Nabi. Jakarta: Bulan Bintang, 1992 M.

al-Jabiri, Muhammad 'Abid. Kritik Perikiran Isam terjemahan Yogyakarta: Fajar Pustaka Baru, 2003 M.

Jamilah, Maryam. Isam dan Mookmisme, terjemahan. Surabaya: al-Ikhlas, tt. al-Jawabi. Juhu $>$ d al-Muhadithi>în Tunis: Muassasah 'Abd al-Karim, 1986 M. al-Jawziyah, Ibn al-Q ayyim. al-Mana $>$ r al-Muni $>$ f fi $>$ al-S $\{a h i>h\}$ wa al-D $\{a \mathrm{ai}>\mathrm{f}$, Beirut: $\mathrm{D}$ a $>\mathrm{r}$ alKutub al-'Ilmiyah, $1988 \mathrm{M}$.

al-Jundi, Abd al-Karim. al-Ima>mal-Sha>fi'i>. Kairo: Da>r al-Kutub al-'Arabi, 1967 M. al-Kattani. al-Risa>lah al-Mustat\}rafah Karaci: Nur Muhammad, 1960 M. Koya (ed.), P.K.. Hadith and Sumah: Idæals and Realities Kuala Lumpur: Islamic Book Trust, 1996 M. al-Khathib, Muhammad 'Ajjaj. al-Sunnah qad al-Tadwi>n Beirut: Da>r al-Fikr, 1971 M. - - - - . Us\}u>l al-H \{adi>th Ulu>mih wa Must\}ala>h\}uh Beirut: Da>r al-Fikr, 1989 M. Khaldun, Ibn. Muqaddmah ibn Khaldr»n ttp.: Da>r al-Fikr, tt. Lammens, H. Isam Beieues and Institutions London: Frank Cass \& Co, 1968 M. Longman. Didionary of Contemparary Engish O xford: Oxford University Press, 1988 M. al-Nawawi. al-Taqi>b li al-Nawa>wi>. Kairo: 'Abd al-Rahman Muhammad, tt. Nasution, Harun. IslamDitinjau dan Bebaagii Aspaknya Jakarta: UI Press, 1985 M. al-Q asimi. Qava>'id al-Tahdi>th fi $>$ Funu>n Mus\}t\}alah\} al-H\{adi>th. Beirut: Da>r al-Kutub al'Ilmiyyah, tt.

Rasyidi, M. Karksi tehadap Hanun Nastion Jakarta: Bulan Bintang, 1977 M. al-Razi, Abu Hatim. Kita>b al-Jarh\} wa al-Ta'di>l. Heiderabad: Majlis Da>irat al-Ma'arif, 1952 M. 
Rayyah, Mahmud Abu. Ad\}wa>' 'ala> al-Summah al-Muhammadiyah Mesir: D a $>$ r al-Ma'arif, tt. al-Siba>'i> Mus\}t\}afa >>. al-Sunnah wa Maka>natuha $>$ fi> al-Tadhi>' al-Isa>m>. Beirut: al-Maktab al-Islami, 1985 M./ $1405 \mathrm{H}$.

S\{ubh $\}$ i $>$ al-S $\{a>$ lih\}. 'Ulu>mal-H adi $>$ th wa Mus\}t\}alah\}huh Beirut: D a $>$ r al-'Tlm li al-Mala>yin, $1988 \mathrm{M}$.

Schacht, Joseph. TheOrigins of Muhammadan Junispudane Oxford: Clarendon Press, 1975 M. al-S\{alah, Ibn. Ulu»mal-H \{adi>th Madinah: Maktabah al-Islamiyah, $1972 \mathrm{M}$. Shaltut, Mahmud. al-Isa>m 'Aqi>dah wa Shari'ah Kairo: Da>r al-Q alam, 1966 M.

Shuhbah, Muhammad Muhammad Abu. Difas' 'an al-Sumnah wa Radd Shubah al-Mustashici $>n$ wa alKutta>b al-Mu'as\}ini>n Kairo: Maktabah al-Azhar, tt.

Suryadi. Metoddog Ilmu Rijalil H\}adi>th Jogyakarta: Madani Pustaka, 2003 M.

al-Suyut\}i $>$. Tadi $>$ b al-Ra $>$ wi> fi $>$ Sharh\} Taqi $>$ b al-Nava $>$ wi $>$. Beirut: Da>r al-Fikr, 1988 M. Syu'bah Asa. "Tamparan untuk Pengingkar H\}adi>th", Majalah Tempo Jakarta, edisi 16 April 1994. al-Tirmisi. Manha>j Dhavi> al-Naz\}a $>$ r. Beirut: Da>r al-Fikr, $1981 \mathrm{M}$.

al-T \{ahhan, Mah\}mu>d. Taysi>r Mus\}t\}ala $>$ h\} al-H $\{$ adi $>$ th Beirut: D a $>$ r al-Q ur'a $>$ n al-Karim, 1979 M.

Wehr, Hans. A Dicianary of Modem Written Arabic London: George Allen \& Unwin Ltd., 1970 M.

Zahrah, Muhammad Abu. al-Sha $>$ fi'i $>\mathrm{H}\{$ aya $>$ tuh wa 'As\}nuh Ara $>$ uh wa Fiknuh Beirut: D a $>\mathrm{r}$ alFikr, tt.

Zahw, Muhammad Muhammad Abu. Al-H\{adi>th wa al-Muh\}adithu>n Beirut: Da>r al-Kutub al'Arabi, 1984 M. 